\title{
Perceived Learning Management Quality Predictors to Motivation and Use of Self-Regulated Learning Strategies
}

\author{
Shayesteh Hashemyolia \\ PhD Student of Educational Technology, Department of Foundation Studies, Universiti Putra Malaysia \\ Email: shayesteh_hashemi@yahoo.com \\ Azizan Asmuni \\ Faculty of Educational Studies, Department of Professional Development and Continuing Education, Universiti Putra Malaysia \\ Email: azizanas@putra.upm.edu.my \\ Ahmad Fauzi Mohd Ayub \\ Faculty of Educational Studies, Department of Foundation studies, University Putra Malaysia \\ Email:afauzi@educ.upm.edu.my \\ Shaffe Mohd Daud \\ Faculty of Educational Studies, Department of Foundation studies, University Putra Malaysia \\ Email: shaffee@upm.edu.my
}

\section{Doi:10.5901/mjss.2015.v6n3s1p428}

\section{Abstract}

The purpose of this research is to investigate learner motivation and self-regulated learning strategies in learning management system (LMS). The study involved 436 undergraduate students used the LMS system for a few months. A structured equation modeling (SEM) was used for analyzing data in the survey study. Statistical results showed that perceived motivation mediated the effect of LMS quality on students' self-regulated learning strategies. Further, motivation had significant effect on students' usage of metacognitive as well as on resource management of self-regulated learning strategies. Finally, the study proposes a conceptual model to learner self-regulated learning in e-learning environment.

Keywords: LMS quality (LMSQ); motivation (MOT); resource management (RSM); metacognitive (MTG)

\section{Introduction}

The use of internet in higher education as a web-based course environment such as learning management system (LMS) is increasing rapidly. Learning in LMS has become highly self-motivated and autonomous and enhances self-regulated learning (SRL) in higher education contexts (Azevedo, Moos, Greene, Winters, \& Cromley, 2008). The personal and social learning space enables borderless limits to teacher-centered concept (Dabbag \& Kitsantas, 2012). In e-learning systems students not only engage in mastering knowledge and skills, but also they have the responsibility to the community in social practices (Greene \& Azevedo, 2009). LMS provides students with a good understanding and opportunity to create and share new ideas and to work as a team (Masrom, Zainon, \& Rahiman, 2008). Although universities facilitate learning and teaching by integrating LMS, they face the challenge with learners' abilities to achieve multiple outcomes such as incorporate new ideas, evaluate complex information, think creatively, and communicate effectively. In contrast, self-regulated learning approach has empowered learners to utilize their metacognitive knowledge to choose appropriate learning strategies for a given task (Vallieres, 2008; Lee \& Tsai, 2011; Pekrun, 2006; Artino, 2009; Azevedo et al., 2008; Greene \& Azevedo, 2009). For this reason, a self-regulation skill is a criterion in successful learning especially in e-learning system (Bol \& Garner, 2011).

Based on social cognitive theory, learning environment affects students' motivation and usage of SRL strategies (Zimmerman, 1989; Artino, 2009; Schuitema, Peetsma, \&Veen, 2012). This study discusses factors that predict motivation and SRL strategies. Based on literature review in educational technology, students' satisfaction of learning 
environment motivated them to learn (Bekele, 2010). Interacting with electronic text can engage students in metacognitive strategies such as goal setting, monitoring, and specific strategy selection (Alexiou1 \& Paraskeva, 2010; Abrami, Bernard, Bures, Borokhovski, Tamim, 2011; Chaiprasurt \&Esichaikul, 2013; Tsai \& Shen, 2009). Accordingly, this study assumed that positive motivation is associated with higher SRL outcomes.

\section{Literature Review}

\subsection{The LMS quality}

Perceived satisfaction of e-learning environment affect students' self-regulated learning (Liaw \& Huang, 2013). According to DeLone and McLeans' model, which is based on constructivism and self-regulatory efficacy, the system, service, and content quality of e-learning environment affect students' satisfaction. The Content quality refers to the degree to which individuals meet their needs, or produce clear output, useful format, and deep involvement (Chen et al., 2009). Service quality is the quality of the system support that users receive from the information system department and support personnel (Petter \& McLean, 2009). System quality is the degree of reliability, convenience, ease of use, functionality, and other system metrics (DeLone \& McLean, 2003).

Regarding the research on supporting e-learning environment and student learning, DuFrene, Lehman, Kellermanns, and Pearson, (2009) argued that if technology is not suited to the students' learning style it may not result in the desired learning effects. In fact, use of technology was related to both perceived and actual student performance. In another study, Lazakidou and Retalis (2010) aimed to present a technology help to develop higher-order thinking skills (SRL strategies) when engaged in problem-solving activities. The study showed that students increased their problemsolving capacity at a shorter time period. In fact, the students' performance in quality and speed was enhanced. Actually, problem-solving instruction could enrich students' autonomy (Zimmerman, 2000) through more flexible, creative and efficient learning environment (Lazakidou \& Retalis, 2010).

In a recent study, Vrieling, Bastiaens, and Stijnen, (2012) indicated that level of metacognitive learning strategies increased with increased SRL opportunities in education programs. Several factors influence participants' motivation for learning that should be considered (1) creating an adequate knowledge by gradually increasing SRL opportunities; (2) giving attention to the conditions that can hinder or foster SRL (3) support student teachers' collaborative learning and (4) develop appropriate learning tasks. The study also found positive correlations between the metacognitive and motivational constructs. Pintrich, (1999) indicated that student motivation and use of learning strategies are related. Students who are more motivated are more likely to use cognitive and metacognitive strategies and gradually receive more complex assignments. In an earlier study conducted by Mouratidis, Vansteenkiste, Michou, and Lens, (2013) it was found that classroom characteristic influences satisfaction. Students' perception of the degree to which teachers provide the necessary information, help, and feedback, increased students competence levels and fostered effective learning strategies. The study found that teacher structure linked with many desired outcomes, including active class engagement, self-determined motivation, and high quality cognitive processes (Mouratidis et al., 2013). Based on literature review this study assumed that students' perception of LMS quality with respect to content, service and system quality can encourage students to learn and get engaged in learning process by using SRL strategies.

\subsection{Learner motivation and use of self-regulation in e-learning environments}

Researches around the world have confirmed the positive relationship between motivation and SRL strategies. Recently, a metadata study drawn from a wide variety of college populations from 7 countries (United States, Canada, Australia Thailand, Taiwan, India, and Malaysia (87.3\% from North America) across several courses indicated that motivation had a positive influence on SRL learning strategies (Credé \& Phillips, 2012). The analysis showed motivation had moderate to large correlations with the various learning strategies. The strongest of these relationships was for effort regulation. It means that students who were engaged in effort regulation had intrinsic interest in academic task, and had a high level of self-efficacy.

The role of motivation to encourage students' use of SRL strategies has been studied in different researches around the world. Liem, Lau, and Nie, (2008) examined the role of self-efficacy, task value, and achievement goals in students' learning strategies, task disengagement, peer relationship, and English achievement outcome. They found that mastery goal orientation predicted metacognitive self-regulated learning with $(\beta=0.32)$ and self-efficacy predicted resource management with $(\beta=0.08)$. Mastery and performance-approach goals were both positive predictors of metacognitive and peer relationship. Mastery goals were also negatively associated with task disengagement and 
positively associated with surface learning. In contrast, performance-avoidance goals were a positive predictor of surface learning and task disengagement but a negative predictor of peer relationship. Hence, these findings suggested that mastery goals and performance-approach goals can generate adaptive outcomes.

Social-cognitive theories emphasize that learning occurs through interactions between learners and the learning environment (Zimmerman, 1989). Thus, students' learning is influenced by their intrinsic motivation and self-efficacy level in e-learning environment (Cleary \& Zimmerman, 2012; Cleary \& Chen, 2009). In this case, Chyung, Moll, \& Berg, (2010) found that intrinsic goal orientation $(\beta=0.35, p=.02)$ significantly predict students learning but self-efficacy had not effect on learning. The researcher suggested finding ways to help students improve and maintain their intrinsic goal orientations and value through specific learning environment such as problem-based learning (PBL).

As conclusion, LMS facilitates management processes such as keeping scores, recording data, and communicating outside the classroom. Students can also receive learning guidance from e-learning modules without the presence of an instructor (Chyung, Moll, \& Berg, 2010). Moreover, based on social cognitive theory, students evaluate learning environments differently. Changes in students' perceptions of environment will change students' thinking, feelings, and actions (Bandura, 1991). Consequently, students' actions vary depending on the level of motivation, learning strategies and learning environment. From a social cognitive perspective, and according to Zimmerman, (1989) $\mathrm{SRL}$ is the degree to which a student actively regulates his motivation, cognitive, and metacognitive behavior.

\section{Research Hypotheses}

The social cognitive theory explains the independent variables and dependent variables of the present study. The SRL is derived from social cognitive theory (Bandura, 1991). The effectiveness of LMS quality is also shown in ISS model from Delone and Maclean (2003) which explains LMS quality in system, service, and content quality. This study seeks to explain the relationship between learning environment (LMS quality) and students, motivation to learn, and use of SRL strategies. Accordingly, the following hypothetical relationships were revealed in this paper.

H1: the students' motivation is influenced by LMS content quality.

$\mathrm{H} 2$ : the students' motivation is influenced by LMS system quality.

H3: the students' motivation is influenced by LMS service quality.

H4: the students' use of metacognitive is influenced by motivation

H5: the students' use of resource management strategies is influenced by motivation

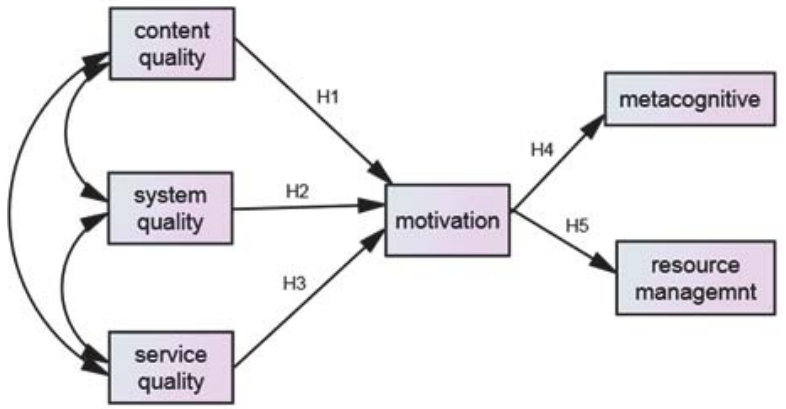

Figure 1. Research Framework and Structural Model

\section{Methodology}

\subsection{Instruments}

This research is based on the PutraLMS e-leaning system. PutraLMS functions include: (a) course management (upload file, file format conversion (PPT,PDF), providing course material with wiki tools, exporting and importing course materials (note, quizzes, assignments) (b) class management (student attendance, students' mark with grading system, student progress reports, calendar of university courses (c) evaluation (teaching evaluation, online quiz, online assignment (based on course or group) (d) communication (e-mail with attachment, discussion / forum, online chat, video conferencing). PutraLMS is a system where lecturers can upload course notes and materials, enter students' tests results, and class attendance, students and lecturers can participate in forums that are the basic features of PutraLMS. 
These modules provide a communication channel for instructors to post messages to courses such as course outline, list of lecture topics, schedules, references and further readings, methods of assessment and contact information. The forum is a tool that allows two-way communication between lecturers and students as well as among students themselves.

\subsection{Participants}

According to Byrene, (2010), the most appropriate minimum ratio for a sample size is five to ten respondents per estimated parameter. Therefore, the questionnaire was distributed to 436 randomly selected undergraduate students in UPM who had used PutraLMS for at least three months. The respondents' age mean was 22.05 , comprising of $66.3 \%$ female and $33.7 \%$ male, Malays (76\%), Chinese (18.8\%), Indian (3.9\%), and others (7\%). More than half of the students $(53 \%)$ had at least three times experience in online learning environment before they enrolled on PutraLMS environment.

\subsection{Measurement}

This study integrated three standard questionnaires with a total of 63 items to measure learners' perception of LMS quality, as well as students' perceptions of motivation to learn, and self-regulated learning strategies. the students' motivation and SRL strategies were measured by Motivated Strategies for Learning Questionnaire (MSLQ) developed by Pintrich, Smith, Garcia, and McKeachie, (1993) in a seven-point Likert scale items (1="Not at all true of me" to 7="Very true of me"). The MSLQ subscales conclude of two dimensions, motivation and learning strategies. The evidence shows that MSLQ is useful, reliable, and valid for assessing college students' motivation and use of learning strategies (Credé, \& Phillips, 2011; Duncan \& McKeachie, 2005; Pintrich et al., 1993). Moreover, LMS quality consists of three dimensions: content quality, system quality, and service quality ( 15 items) suggested by Lee and Lee (2008) at $(\alpha=0.84)$. Therefore, three-factor questionnaire covered 15 items and each item was on a 5-point Likert scale ( 1 = "strongly disagree" to $5=$ "strongly agree").

\section{Analyzing}

This study used Structural Equation Modeling (SEM) to analyses data in following two-stage procedure:

\subsection{Analysis of the measurement model}

The first stage is assessing the individual constructs' reliability, measuring model validity and number of Goodness-Of-Fit (GOF). The confirmatory factor analysis (CFA) indicated the adequacy of the factor loadings, comparisons fit indices of CMIN $=1070.352, P=.000, \mathrm{CMIN} / \mathrm{df}=1.760$, incremental fit Index $(\mathrm{IFI})=.954$, comparative fit index $(\mathrm{CFI})=.954$, goodnessof-fit index $(\mathrm{GFI})=.883$, and root mean square error of approximation (RMSEA) $=.042$ (Hair et al., 2010). Based on Table1, all items Cronbach's alpha (CA) and composite reliability (CR) are more than threshold value 0.7 that indicated measurement model reliability (Urbach et al., 2010). Moreover, Average Variance Extracted (AVE) for all items was above 0.5 cut of value that indicated the validity of measurement model (Fornell, \& Larcker, 1981).

Table 1. Construct Validity and Convergent Validity

\begin{tabular}{cccccc}
\hline Construct/indicator & Questionnaire items & Factor loading & $\begin{array}{c}\text { Composite } \\
\text { reliability (CR) }\end{array}$ & $\begin{array}{c}\text { Cronbach' alpha } \\
\text { (CA) }\end{array}$ & $\begin{array}{c}\text { Average variance } \\
\text { extracted (AVE) }\end{array}$ \\
\hline CON & CON1 & .74 & .864 & .863 & .559 \\
& CON2 & .73 & & & \\
& CON3 & .72 & & & \\
& CON4 & .79 & & & \\
\hline SYS & CON5 & .75 & & & .550 \\
& SYS1 & .72 & .859 & & \\
& SYS2 & .75 & & & \\
& SYS3 & .79 & & & \\
& SYS4 & .71 & & & \\
SYS5 & .74 & & & \\
\hline
\end{tabular}




\begin{tabular}{|c|c|c|c|c|c|}
\hline SER & $\begin{array}{l}\text { SER1 } \\
\text { SER2 } \\
\text { SER3 } \\
\text { SER4 } \\
\text { SER5 }\end{array}$ & $\begin{array}{l}.72 \\
.78 \\
.84 \\
.83 \\
.74\end{array}$ & .884 & .881 & .604 \\
\hline MOT & $\begin{array}{l}\text { INC } \\
\text { TAS } \\
\text { SEL }\end{array}$ & $\begin{array}{l}.843 \\
.858 \\
.837\end{array}$ & .890 & .883 & .670 \\
\hline RSM & $\begin{array}{l}\text { TIM } \\
\text { EFT } \\
\text { P\&H }\end{array}$ & $\begin{array}{l}.833 \\
.809 \\
.855 \\
\end{array}$ & 883 & .910 & .716 \\
\hline MTG & $\begin{array}{c}\text { MTG2 } \\
\text { MTG3 } \\
\text { MTG4 } \\
\text { MTG5 } \\
\text { MTG6 } \\
\text { MTG7 } \\
\text { MTG9 } \\
\text { MTG10 } \\
\text { MTG11 } \\
\text { MTG12 }\end{array}$ & $\begin{array}{l}.728 \\
.804 \\
.772 \\
.757 \\
.818 \\
.815 \\
.824 \\
.811 \\
.791 \\
.685\end{array}$ & .940 & .865 & .611 \\
\hline
\end{tabular}

Content quality (CON), service quality (SER), system quality (SYS), motivation (MOT), resource management (RSM), metacognitive (MTG)

The result of diagonal correlation matrix, for the measurement model in Table 2 shows satisfactory discriminant validity for all variables. According to Fornell and Larcker (1981), AVE of all variables is larger than squared correlation between variables in the model. Therefore, the discriminant validity is satisfactory.

Table 2. Correlation Matrices and Discriminant Validity

\begin{tabular}{ccccc}
\hline Construct & LMSQ & MOT & MTG & RSM \\
\hline LMSQ & $(.609)^{\star \star}$ & & & \\
MOT & $.286^{\star \star}$ & $(.653)^{\star \star}$ & & \\
MTG & $.173^{\star \star}$ & $.172^{\star \star}$ & $(.611)^{\star \star}$ & $(.619)^{\star \star}$ \\
RSM & $.245^{\star \star}$ & $.242^{\star \star}$ & $.378^{\star \star}$ & $(.62$ \\
\hline
\end{tabular}

Note: ${ }^{* *} p<0.01$

\subsection{Analysis of the Structural Model}

The second stage is examining the structural model to determine the strength and direction of the relationships among the theoretical constructs. The full structural model of the hypothesized relationships was statistically tested using AMOS 6.0, a software package designed to perform a structural equation model (SEM). The reason for using the SEM approach is to better view the whole research model rather than multiple regression approach. The result revealed chi-square= 1203.818, $\mathrm{p}=0.00$, chi-square/df= 1.951, GFI= 0.870, $\mathrm{CFI}=0.942$, NFI= 0.888, $\mathrm{FII}=.942$, and RMSEA $=0.047$. Generally, fit statistics (GFI, NFI, and CFI) greater than or equal to 0.9 indicate a good model fit (Hair et al., 2010). 


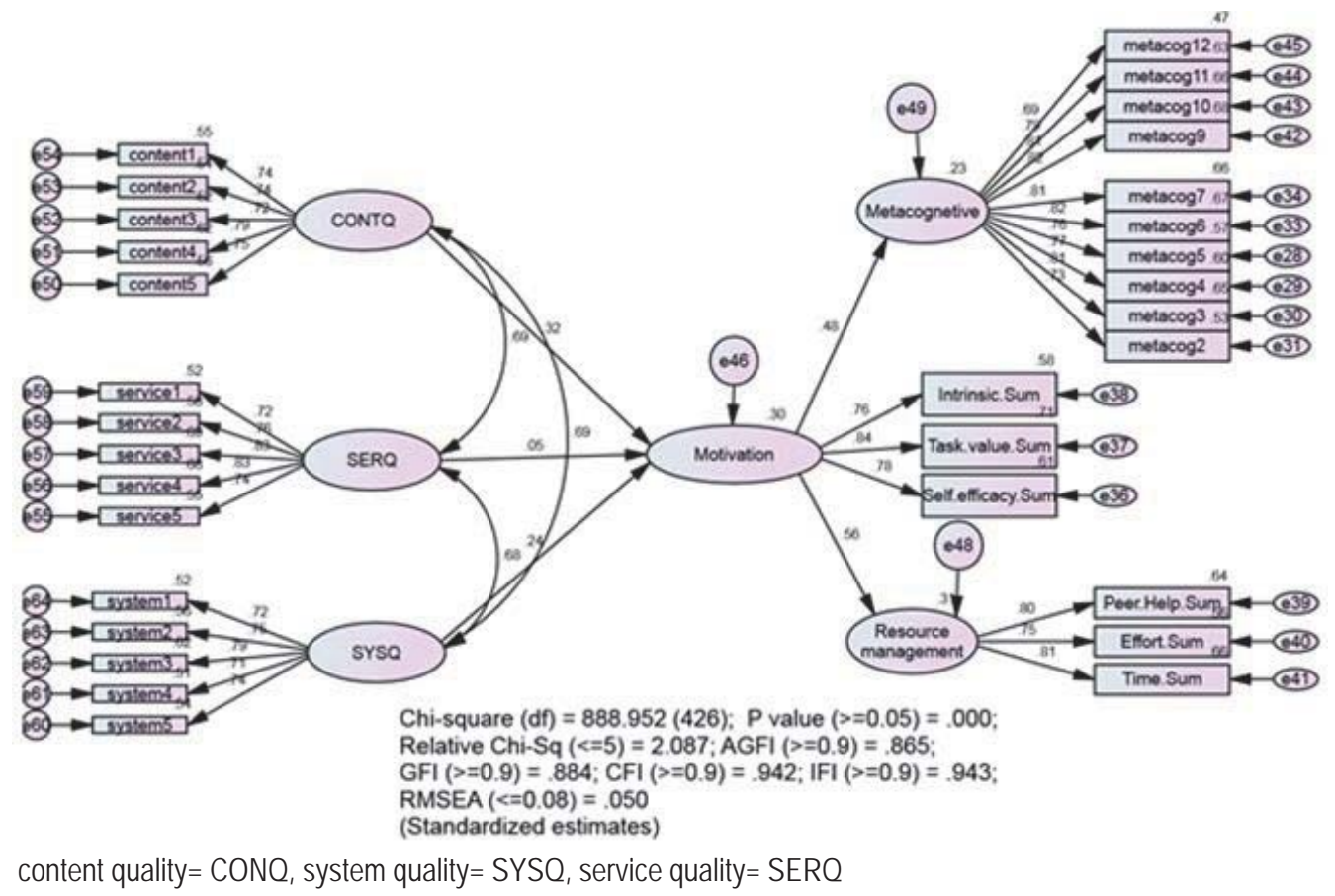

Figure 2. The Result of Hypothesis

\subsection{Hypotheses Examination}

The six hypotheses were tested collectively using the SEM approach. The path significance of each hypothesized association in the research model is examined and variance explained $\left(R^{2}\right)$ by each path. Figure 2 and Table 3 respectively show the standardized path coefficients and path significances.

According to the result obtained, content quality was positively related to perceived motivation $(\beta=0.194, p<0.05)$, and system quality significantly related to motivation $(\beta=0.162, p<0.05)$. Thus, hypothesis $\mathrm{H} 1$ and $\mathrm{H} 2$ were supported. However, service quality could not predict students' motivation $(\beta=-.053, p=.491)$. With respect to $\mathrm{H} 4-\mathrm{H} 5$, perceived motivation was positively related to students use metacognitive learning strategies $(\beta=0.496, p<0.01)$, and resource management strategies $(\beta=0.568, p<0.01)$.

Table 3. Summary of Hypotheses' Testing

\begin{tabular}{ccccc}
\hline No & Hypothesis & $\boldsymbol{\beta}$ & $\mathbf{P}$ & Support \\
\hline H1 & CON $\rightarrow$ MOT & .194 & .018 & Yes \\
H2 & SYS $\rightarrow$ MOT & .162 & .039 & Yes \\
H3 & SER $\rightarrow$ MOT & -.053 & .491 & No \\
H4 & MOT $\rightarrow$ MTG & .496 & $\star * \star$ & Yes \\
H5 & MOT $\rightarrow$ RSM & .568 & $* \star *$ & Yes \\
\hline *** p p.001 & & & &
\end{tabular}

The predictors of motivation explain $41.2 \%$ of its variance; resource management explains $32.2 \%$ of its variance and metacognitive strategies explain $24.6 \%$ of its variance. In other words, these three variables together explain $95 \%$ of the variance $\left(\mathrm{R}^{2}=.65\right)$.

\section{Discussion}

Based on our research hypotheses, students' motivation to learn through LMS environment is predicted by content quality, system quality. Student's usage of metacognitive and resource management strategies is affected by motivation of learning in LMS learning environment. From the results of statistical analysis as shown in Table 3 all hypotheses are 
supported except for hypothesis 3. It means that perceived service quality is neither a positive nor a negative factor on students' learning motivation in LMS environment. Although, DeLone and McLean, (2003) and Hassanzadeh, Kanaani, and Elahi's (2011) stated perceived service quality is related to satisfaction, it may not be a critical factor to predict motivation. Future research should be conducted to investigate this issue. The result of other five hypotheses, correspond to those of previous studies. It means that perceived content quality and system quality are significant factors that affect learner motivation and use of SRL strategies (Kramarski \& Gutman, 2006; Torkzadeh et al., 2006; Liaw \& Huang, 2013).

This study is agreeable with past research findings that students' motivation determined their use of metacognitive and resource management self-regulated learning strategies (Bandura, 1991; Yang, Tsai, Kim, Cho, Laffey, 2006; Saribasa, \& Bayramb, 2009; Cleary and Chen, 2009; Walker, Greene, and Mansell, 2006). Likewise, Jager et al., (2012) found that task value beliefs and self-efficacy were positively related to deep learning strategies (metacognitive). Walker et al., (2006) also indicated that intrinsic motivation and self-efficacy predict self-regulatory strategies such as planning and checking one's work.

This study showed that students are responsible for their own learning process and engage in SRL when they perceive content as interesting and when they are satisfied with the LMS task provided by the lecturer. When a topic is regarded as interesting and important or useful for the student, they tend to use more SRL strategies (Pintrich, et al.,1993). Cleary and Chen, (2009) also found that interest in a given task was a motivational predictor of students' use of SRL strategies in mathematics course. The results of this research support previous researches that self-regulation could be influenced by perceived characteristics of learning environment (Artino, 2009; Young, 2005; Kramarski \& Gutman, 2006).

The findings of this study provide direction for LMS management and lecturers to make an effective LMS initiative. LMS system, content quality as a technology which aid in supporting teaching and learning should be provided by the LMS management. When the lecturer is able to successfully incorporate LMS into teaching practices in supporting student SRL, the students will definitely benefit from the use of LMS in SRL. Students in LMS learning environment specially need more SRL because of their flexibility of time, place and resource information. Students should be able to change learning strategies based on their needs and learning environment.

\section{Conclusion}

This study investigated the relationship between the development of students' self-regulated learning and students' perceptions of the learning environment in terms of LMS quality. In other words, this study investigated whether LMS learning environment foster students' SRL. The findings revealed that learning environments give the opportunities to students to engage in SRL strategies. Our research findings support the social cognitive theory, that LMS environment quality predicted students' motivation as well as students' use of SRL strategies. The learner successful in e-learning environment is dependent of students use SRL strategies. On other hands, the learner capability of using SRL strategies is related to effective e-learning environment. Therefore, learning environment, students' motivation, and learning strategies are combined together to predict students successful in LMS environment.

The advantage of this study can be help LMS designer to provide effective learning environment. One of the stakeholders of this study can be the instructor who should identify what characteristic of environment would be helpful for students' motivation and use of SRL strategies. The other stakeholders of this study are students who engage in LMS environment. They should know how to learn and when and where use different learning strategies while they are in independent learning environment. They should know about weakness and strange in using SRL especially in LMS environment.

This study was limited to undergraduate students who used PutraLMS. For this reason the results of study might be dependent on the PutraLMS program and the sample, therefore more research needs to be conducted on this area. The other limitation is that this study considered only three dimensions of motivation and two components of SRL strategies. Further research could also possibly be carried out to develop SRL model based on other variables.

\section{References}

Abrami, P. C., Bernard, R. M., Bures, E. M., Borokhovski, E., \& Tamim, R. M. (2011). Interaction in distance education and online learning: using evidence and theory to improve practice. Comput High Educ, 23, 82-103.

Alexioua, A., \& Paraskeva, F. (2010). Enhancing self-regulated learning skills through the implementation of an e-portfolio tool. Procedia Social and Behavioral Sciences, 2, 3048-3054.

Alexioua, A., \& Paraskeva, F. (2013). Exploiting Motivation and Self-efficacy through the Implementation of a Self-Regulated Oriented e- 
Portfolio. The International Conference on E-Learning in the WorkplaceICELW, 12, 14.

Artino, A, R., \& Stephens, J, M. (2009). Academic motivation and self-regulation: A comparative analysis of undergraduate and graduate students learning online. Internet and Higher Education, 12, 146-151.

Artino, A. (2009). Think, feel, act: Motivational and emotional influences on military students' online academic success. Computing in Higher Education, 21 (2), 146-166.

Azevedo, R. (2005). Using hypermedia as a metacognitive tool for enhancing student learning? The role of self-regulated learning,Educational Psychologist, 40, 199-209.

Azevedo, R., Moos, D.C., Greene, J. A., Winters, F. I., \&Cromley, J.G. (2008). Why is externally-facilitated regulated learning more effective than self-regulated learning with hypermedia? Education Tech Research, 56, 45-72.

Bandura, A. (1991). Social cognitive theory of self-regulation. Organizational Behavior and Human Decision Processes, 50, 248-281.

Bekele, T. A. (2010). Motivation and satisfaction in internet-supported learning environments: A Review. Educational Technology \& Society, 13 (2), 116-127.

Bol, L., \& Garner. J. K, (2011). Challenges in supporting self-regulation in distance education environments. Comput High Educ, 23,104123.

Byrne, B. M. (2010). Structural equation modeling with AMOS: basic concepts, applications, and programming, Taylor \& Francis Group, 2nd ed, New York.

Chaiprasurt, C \& Esichaikul, V. (2013). Enhancing Motivation in Online Courses with Mobile Communication Tool Support, A Comparative Study.

Chyung, S. Y., Moll, A. J., \& Berg, S. A. (2010). The Role of Intrinsic Goal Orientation, Self-Efficacy, and E-Learning Practice in Engineering Education. Effective Teaching, 10 (1), 22-37.

Cleary, T.J., \& Zimmerman, B.J. (2012).A cyclical self-regulatory account of student engagement: theoretical foundations and applications. Handbook of Research on Student Engagement. New York,USA.

Cleary, T., \& Chen, P, P (2009). Self-regulation, motivation, and math achievement in middle school: Variations across grade level and math context. School Psychology, 47, 291-314.

Credé, M., \& Phillips, A, L. (2012).A meta-analytic review of the Motivated Strategies for Learning Questionnaire. Learning and Individual Differences, 21, 337-346.

DeLone, W. H., \& McLean, E. R. (2003). The Delone and Mclean model of information systems success: a ten-year update. Management Information System, 19, 4, 9-30.

DuFrene, D. D., Lehman, C. M., Kellermanns, F. W., \& Pearson, R. A. (2009). Do business communication technology tools meet learner needs? Business Communication Quarterly, 72, 2, 146-162.

Duncan, T.G., \&McKeachie, W.J. (2005).The making of the motivated strategies for learning questionnaire. Educational Psychologist, 40 (2), 117-128.

Fornell, C., \& Larcker, D. F. (1981). Evaluating structural equation models with unobservable variables and measurement error. Journal of Marketing, 1(1), 39-50.

Greene, J.A., \&Azevedo, R. (2009).A macro-level analysis of SRL processes and their relations to the acquisition of a sophisticated mental model of a complex system. Contemporary Educational Psychology, 34, 18-29.

Hair, J. F., Anderson, R. E., Tantham, R. L., \& Black, W. C. (2010). Multivariate data analysis, (5 th). New Jersey: Prentice Hall.

Hassanzadeh, A., Kanaani, F., \& Elahi, S. (2011). A model for measuring e-learning systems success in universities. Expert Systems with Applications, $3,6$.

Ho, R. (2006). Hand book of univariate and multivariate data analysis and interpretation with SPSS. Poblished by Chapman.Central Queensland University. Rockhampton, Australia.

Huang, J., Yang, S., \& Chang, M. (2011). The effect of ePortfolio satisfaction on students' learning motivationand Internet self-efficacy. Educational Technology Development and Exchange, 4 (1), 103-118.

Jager, K, S., Schotanus, J, C., \& Themmen, A, N. (2012). Motivation, learning strategies, participation and medical school performance. Medical Education, 46, 678- 688.

Kramarski, B., \& Gutman, M. (2006). How can self-regulated learning be supported in mathematical E-learning environments? Computer Assisted Learning, 22, 24-3.

Kuo, Y, C. (2010). interaction, internet self-efficacy, and self-regulated learning as predictors of student satisfaction in distance education courses, Doctor of Philosophy in Instructional Technology and Learning Sciences, Utah state university.

Lazakidou, G., \& Retalis, S. (2010). Using computer supported collaborative learning strategies for helping students acquire selfregulated problem-solving skills in mathematics, Computers \& Education, 54, 3-13.

Lee, S. W., \& Tsai, C. C. (2011).Students' perceptions of collaboration, self-regulated learning, and information seeking in the context of Internet-based learning and traditional learning. Computers in Human Behavior, 27, 965-914.

Liaw, S., \& Huang, H. M. (2013). Perceived satisfaction, perceived usefulness and interactive learning environments as predictors to self-regulation in e-learning environments. Computers \& Education, 60, 14-24.

Liaw, S,S. (2008). Investigating students' perceived satisfaction, behavioral intention, and effectiveness of e-learning: A case study of the Blackboard system. Computers \& Education, 51, 864-873.

Liem, A, D., Lau, S., \& Nie, Y. (2008). The role of self-efficacy, task value, and achievement goals in predicting learning strategies, task disengagement, peer relationship, and achievement outcome. Contemporary Educational Psychology, 33, 486-512.

Masrom, M., Zainon, O., \& Rahiman, R. (2008). E-Learning Critical Success Factors: The Students' Perspective. In Mohd.Nazirmd.Basri 
(2008). E-learning issues in Malaysian higher education, MohdFuadMohdSalleh, UniversitiTeknologi Malaysia.

Mouratidis, A., Vansteenkiste, M., Michou, A., \& Lens, W. (2013).Perceived structure and achievement goals as predictors of students' self-regulated learning and affect and the mediating role of competence need satisfaction. Learning and Individual Differences, 23, 179-186.

Pekrun, R. (2006). The control-value theory of achievement emotions: Assumptions, corollaries, and implications for educational research and practice. Educational Psychology Review, 18, 315 - 341.

Petter, S., \& McLean, E. R. (2009). A meta-analytic assessment of the DeLone and McLean IS success model: An examination of IS success at the individual level. Information \& Management, 46, 159-166.

Pintrich, P. R., Roeser, R. W., \& De Groot, E. A. (1993).Classroom and Individual Differences in Early Adolescents' Motivation and SelfRegulated Learning. journal of early adolescence, 14 (2), 139-161

Pintrich, P. R., Smith, D.A.F., Garcia, T., \& McKeachie, W. J. (1993). Reliability and predict validity of motivated strategies for learning questionnaire (MSLQ). Educational psychological measurement, 53 (3), 801-810.

Pintrich, P.R. (1999). The role of motivation in promoting and sustaining self-regulated learning. International Journal of Educational Research, 31, 459-470.

Saribasa, D., \& Bayramb, H. (2009). Is it possible to improve science process skills and attitudes towards chemistry through the development of metacognitive skills embedded within a motivated chemistry lab?, a self-regulated learning approach, Procedia Social and Behavioral Sciences, 1, 61-72.

Schuitema, J., Peetsma, T., \& Veen, I. V. (2012). Self-regulated learning and students' perceptions of innovative and traditional learning environments: a longitudinal study in secondary education. Educational Studies, 38 (4), 397-413.

Torkzadeh. G., \& Dyke, T.V. (2001). Development and validation of an Internet self-efficacy scale. Behaviour \& Information Technology, 20 (4), 275-280.

Tsai, C.W., \& Shen, P.D. (2009).Applying web-enabled self-regulated learning and problem-based learning with initiation to involve lowachieving students in learning. Computers in Human Behavior,25, 1189-1194.

Urbach, N., Smolnik, S., \& Riempp, G. (2010). An empirical investigation of employee portal success. Journal of strategic Information Systems, 19 (3), 184-206.

Vallieres, K. M. (2008). Adult learning in Web-based faculty professional development: The role of self-regulation and interaction. University of Connecticut.

Vovides, Y., Sanchez-Alonso, S., Mitropoulou, V., \& Nickmans, G. (2007). The use of e learning course management systems to support learning strategies and to improve selfregulated learning. Educational Research Review, 2 (1), 64-74.

Vrieling, E, M., Bastiaens, T, J., \& Stijnen, S. (2012). Effects of increased self-regulated learning opportunities on student teachers' metacognitive and motivational development. International Journal of Educational Research, 53, 251-263.

Walker, C.O., Greene, T. B., \& Mansell, R. A. (2006).Identification with academics, intrinsic/extrinsic motivation, and self-efficacy as predictors of cognitive engagement. Learning and Individual Differences, 16, 1-12.

Yang, C.C., Tsai, C., Kim, B., Cho, M., \&Laffey, J.M. (2006).Exploring the relationships between students' academic motivation and social ability in online learning environments. Internet and Higher Education, 9, 277-286.

Young, M, R. (2005). The motivational effects of the classroom environment in facilitating self-regulated learning. Journal of Marketing Education, 27(1), 25-40.

Zimmerman, B.J. (1989b). A social cognitive view of self-regulated learning, Journal of Educational Psychology, 81 (3), $329-339$. 